Georgetown University Law Center

Scholarship @ GEORGETOWN LAW

1998

\title{
A Tribute to Jonathan Mann: Health and Human Rights in the AIDS Pandemic
}

Lawrence O. Gostin

Georgetown University Law Center, gostin@law.georgetown.edu

This paper can be downloaded free of charge from:

https://scholarship.law.georgetown.edu/facpub/747

26 J.L. Med. \& Ethics 256-258 (1998)

This open-access article is brought to you by the Georgetown Law Library. Posted with permission of the author. Follow this and additional works at: https://scholarship.law.georgetown.edu/facpub

Part of the Health Law and Policy Commons, and the Human Rights Law Commons 


\title{
A Tribute to Jonathan Mann: Health and Human Rights in the AIIDS Pandemic
}

\author{
Lawrence O. Gostin
}

It was a characteristically cold, bright morning in Geneva in 1986, and I had just taken the Number 8 bus from the Cornavin to the headquarters of the World Health Organization (WHO). I wandered into a cluttered and cramped office filled with unopened boxes and scattered papers. Jonathan Mann and a competent Swiss secretary, Edith Bernard, had just moved in. Together, they alone constituted the WHO team that would mobilize the global effort against an emerging plague-the acquired immunodeficiency syndrome (AIDS). Jonathan had recently come from Kinshasa where he led Projet SIDA, an innovative international program to reduce the already weighty burden of the human immunodeficiency virus (HIV) in Africa. Jonathan had a disarmingly illuminating smile, an indefatigable personality, and penetrating eyes that revealed an inner determination to prevail against enormous odds. I recall wondering how it would be possible, even for a person with Jonathan's heart and skills, to place a check on the seemingly relentless course of the AIDS pandemic.

I left Geneva several days later, returning to Harvard where I watched Jonathan build the WHO Global Programme on AIDS (GPA) into the largest program in the history of WHO. In just four years, GPA em- ployed 280 people with a $\$ 109$ million annual budget. More than money, Jonathan developed a cadre of loyal professionals who, then and now, have become global leaders in the AIDS pandemic-Jim Chin, Jose Esparza, David Heymann, Kathleen Kay, Tom Netter, Daniel Tarantola, Roy Widdus, and many others. At the Centers for Disease Control (CDC), he worked with Jim Curran and, at Projet SIDA, with Peter Piot, both of whom, with Jonathan, changed the course of the AIDS pandemic. From humble beginnings, with a gentle dynamic leader and his secretary, world mobilization against AIDS grew until it culminated in the Joint United Nations Programme on HIV/AIDS, currently led by Jonathan's friend, Piot.

During those years at WHO, as Gordon Nary stated, "the impact of his unrelenting leadership may have had as profound an effect on the global HIV community as any AIDS drug." That alone-his mobilization of the world against AIDS-is Jonathan's greatest legacy.

I saw Jonathan often during his reign at WHO and observed his passionate belief that AIDS was not only a medical or scientific phenomenon, but also a social issue. Jonathan organized a series of expert meetings at WHO where he created consensus among world AIDS leaders against compulsory testing and exclusion of persons living with HIV/AIDS from employment, insurance, travel, and immigration. Persons who had long fought against human rights invasions-Sev Fluss, June Osborne, and Ronald Bayer, to name a few-joined forces to condemn the social and economic exclusion of persons with AIDS. Jonathan also included persons living with HIV/AIDS and community-based organizations in the consensus-building process, an approach that was visionary at that time. Jonathan's own words, spoken at the World AIDS Summit in London in 1988, best capture his remarkable insight and soft compassion: "We live in a world threatened by unlimited destructive force, yet we share a vision of creative potential.... AIDS shows us once again that silence, exclusion, and isolation-of individuals, groups, or nations-creates a danger for us all."

When Jonathan left WHO in 1990 , in part due to his principled stand against then Director-General Hiroshi Nakajima, he was determined to combine two of his deepest passions in life-human health and human rights. Later that year, he and I boarded a crowded trolley car in a Boston suburb bound for the Longwood medical area, and I talked to him about com- 
ing to the Harvard School of Public Health (HSPH). He was on his way to meet Harvey Fineberg, then dean of the HSPH and now provost of Harvard University. Jon displayed such open-heartedness and depth of feeling about his days at WHO that I was drawn to him.

When he arrived at Harvard, we worked together on what we believe was the first course ever given on health and human rights. We taped ail of the lectures for posterity. (I still offer that course on health and human rights at Johns Hopkins and Georgetown Universities.) Students at the HSPH were captivated by Jon's passion for human rights. After his first year, Fineberg aptly called him both the school's Rookie of the Year and Most Valuable Player. Even before Jonathan joined the faculty of the $\mathrm{HSPH}$, he had a profound effect on the institution and its students. While he headed GPA, Jon suggested that the HSPH give each graduate a copy of the Universal Declaration of Human Rights. As Fineberg explains, "In Jon's eyes, this was the equivalent in public health of the Hippocratic Oath in medicine." Ever since that time, the HSPH has given a copy of the Universal Declaration on Human Rights to each of its graduates-a fitting tribute to Jonathan.

In 1992, the VIII International Conference on AIDS/III STD World Congress was scheduled to take place at Harvard University, and Jonathan was asked to chair it. In a courageous stand against discrimination, the International AIDS Society declined to hold the conference in the United States because the U.S. government had erected travel restrictions against persons living with HIV/AIDS. Jonathan, refusing to countenance the cancellation of a major international AIDS meeting, organized a memorable conference in Amsterdam in July 1992. The theme of the meeting, "A World United Against AIDS," symbolized his global vision of HIV prevention and human rights.
In 1993, Albina du Boisrouvray, a Swiss countess who was convinced of Jon's genius, donated $\$ 20$ million to Harvard to establish the FrançoisXavier Bagnoud Center for Health and Human Rights. The Center was named in honor of her son, who had died in a helicopter crash in Africa in 1986. Jonathan became the first professor and director of the Bagnoud Center, where he founded the Journal of Health and Human Rights, edited AIDS in the World, and held the first international conference on health and human rights.

The lead article in the first issue of the journal, co-written by Mann, set out the three relationships between health and human rights: (1) the impact of health policies, programs, and practices on human rights-public health policies, such as compulsory testing and isolation, can themselves affect the rights of people; (2) health impacts resulting from violations of human rights-violations of human rights such as torture, inhuman, and degrading treatment and sexual or racial discrimination affect population health; and (3) the inextricable linkage between health and human rights - a synergistic relationship exists between the promotion of health and of human rights.

Jon left Harvard at the end of 1997, accepting a position as the founding dean at a new school of public health at Allegheny University, in Philadelphia. His innovative plan was to dedicate an inner city school of public health to the problems of poverty and social inequality, and the advancement of human rights. With Sofia Guskin and me, he created courses in health and human rights for CDC and the U.S. Agency for International Development. It was gratifying to see the enthusiasm with which these agencies embraced human rights. During these two-to-three-day courses, he would discuss his new theory of health and human rights. Human ill-health, he would argue, is more than just germ or behavioral theories; disease is prin- cipally about dignity violation. He was in the process of creating a taxonomy of dignity violation that would transform the way we think about public health. Jonathan also emphasized the importance of education and improving the status of women as public health priorities.

It is difficult to describe Jon's pure humanity, but everyone who knew him recognized it. Jon was full of life-high spirited, vibrant, and enterprising, with an infectious optimism about the possibilities of preventing disease and eliminating social injustice. His characteristic bow tie, broad smile, and polished discourse made him a dashing figure. But beyond his charisma, leadership, and capacity to change the world was his humanity. Jon was a compassionate, open-hearted person with empathy and caring for those who, in his words, were "cast into the shadows" by persons, groups, and nations.

Perhaps you can best understand a person by his family. Jonathan lived a life filled with love and fulfillment. He was surrounded by loving soulmates, first, by Marie-Paule Bondat, a treasure of a woman who is vibrant, nurturing, and supportive. And, of course, most recently, by Mary Lou Clements-Mann, a deeply beloved woman, confidant, and internationally eminent scientist in her own right. Jonathan was a doting and compassionate father, and perhaps his children have suffered the most unfathomable loss. Jonathan was enormously proud of his children who, in many ways, have followed his vision-Naomi, a student of mine at Georgetown University Law Center who will work on the rights of women; Lydia, a dedicated social health worker in Boston; and Aaron, a Peace Corps volunteer in Africa. I know that Jon would have said that, of all of the many marvelous things in his life, Naomi, Lydia, and Aaron were the most wonderful.

\section{References}

1. J. Mann et al., "Health and Hu- 
man Rights," Journal of Health and Human Rights, 1 (1994): 6-22. See also L.O. Gostin and Z. Lazzarini, Human Rights and Public Health in the AIDS Pandemic (New York: Oxford University Press,
1997) (with a foreword by the director of the United Nations Programme on HIV/ AIDS and the United Nations High Commissioner on Human Rights, and an Afterword by Jonathan Mann).
Lawrence O. Gostin, J.D. Professor of Law \& Public Health Georgetown University and Johns Hopkins University Washington, D.C. 